\title{
Short Communication: Biodegradable of bio-composites made from Polylactid Acid (PLA) and cellulose fibers from oil palm empty fruit bunch
}

\author{
YULIATI INDRAYANI ${ }^{1, \bullet}$, LISMAN SURYANEGARA ${ }^{2}$, SAERI SAGIMAN ${ }^{3}$, EMI ROSLINDA $^{1}$, MARWANTO $^{1}$ \\ ${ }^{1}$ Faculty of Forestry, Universitas Tanjungpura. Jl.Imam Bonjol Pontianak 78124, West Kalimantan, Indonesia. Tel./fax.: +62-815-2285-0200, \\ "email: mandaupermai@yahoo.com. \\ ${ }^{2}$ Research Center for Biomaterials, Indonesian Institute of Sciences. Jl. Raya Bogor Km. 46, Cibinong, Bogor 16911, West Java, Indonesia \\ ${ }^{3}$ Faculty of Agriculture, Universitas Tanjungpura. Jl.Imam Bonjol, Pontianak 78124, West Kalimantan, Indonesia
}

Manuscript received: 9 October 2018. Revision accepted: 12 December 2018

\begin{abstract}
Indrayani Y, Suryanegara L, Sagiman S, Roslinda E, Marwanto. 2019. Short Communication: Biodegradable of biocomposites made from Polylactic Acid (PLA) and cellulose fibers from oil palm empty fruit bunch. Nusantara Bioscience 11: 8-11. Over the last two decades, plastic has become an integral part of people's everyday life. However, plastic is a material that difficult to be degraded in the environment. Due to environmental concern, it is indispensable to find environmentally friendly plastic materials. This study aimed to determine the biodegradable polymer composites manufacture from cellulose fibers of oil palm empty fruit bunches (OPEFB) and polylactic acid (PLA). Cellulose fibers from oil palm OPEFB were isolated by chemical methods. Polymer composites made by mixing cellulose fiber of oil palm OPEFB and PLA based on differences in the composition of the cellulose fiber of OPEFB. The composition used is 0 PHR, 5 PHR, 10 PHR, 15 PHR, and 20 PHR. Results showed that polymer composite with higher composition of cellulose fiber of OPEFB more easily degraded in the environment. There are no significant differences in biodegradable between 15 PHR and 20 PHR, neither among 10 PHR, 5 PHR and control. At higher cellulose fiber of OPEFB content, 20 PHR, polymer composite was the most degraded in the environment.
\end{abstract}

Keywords: Biodegradation, Bio-plastic, Cellulose fiber, Oil palm empty fruit bunches (OPEFB), Polylactic acid (PLA).

\section{INTRODUCTION}

Plastic is one of the materials that are easily found at present. Many items are made from plastic-based materials such as plastic packaging and furniture. This is due to the properties of plastics such as elastic, light but strong, transparent, and waterproof. However, the weakness of this material is difficult to decompose in the environment so that it can cause environmental pollution. This is because the ability of decomposers to decompose plastics in the soil naturally can reach hundreds of years. Decomposers consist of several microorganisms and bacteria, fungi and actinomycetes (Herdiyantoro, 2010).

One of the solutions to overcome the problem of plastic waste is to replace or modify the main material in conventional plastics such as petroleum, natural gas and coal by using environmentally friendly materials (easily degraded). One of the natural based polymers is polylactic acid (PLA). PLA is a biopolymer composed of fermented lactic acid monomers from agricultural materials such as corn starch. As a matrix in plastic composites, PLA has advantages such as biodegradable, sustainable, and can be processed with ordinary machines for conventional plastic. However, PLA also has disadvantages such as not being able to process at high temperatures and a slow crystallization process that inhibits the production process.

The disadvantages of PLA properties can be improved by adding filler ingredients. The filler that is widely used in composite plastics is cellulose fiber. Research on the use of cellulose fibers from fibrous flax and cotton linters (Mostafa et al. 2018) and Manila hemp (Ochi, 2011) for biodegradable plastic manufacturers has been investigated. Cellulose fibers can be produced from mechanical, chemical processes or a combination of both from a source of material containing other lignocellulose such as oil palm. Currently, oil palm is one of the commodities that are growing rapidly. The area of oil palm plantations in Indonesia in 2013 was 10.465 .020 ha and increased to 10.956.231 ha in 2014 and in 2015 reached 11.444.808 ha (Directorate General of Plantation, 2014). This plantation area is increasing every year, and in 2018 was noted reaching 14.030.000 ha (Kompas.com, 2018). Empty oil palm fruit bunches (OPEFB) is the biggest waste with no economic value. Since the number of OPEFB is very abundant, the use of cellulose from OPEFB waste as a PLA amplifier is very prospective. Dewanti (2018) said that the cellulose from OPEFB potential used for bio-plastic manufactures reached 2,097,225 million tons. Therefore, it is necessary to do research on the effect of the addition of cellulose fibers from OPEFB on PLA composites to their ability to decompose in the environment. 


\section{MATERIALS AND METHODS}

\section{Material preparation}

OPEFB was air dried and then cut into small pieces approximately $2 \mathrm{~cm}$. Afterward, the OPEFB was enumerated using a ringflaker. The OPEFB particles from the ringflaker were refined using a hammer mill with 2 times repetition so that the particles became smoother. OPEFB powder was then filtered using sieve of 40 mesh and 60 mesh. The OPEFB powder used in this study was passed from 40 mesh sieve and held 60 mesh.

\section{Production of pure cellulose}

A cellulose production method referred to Sun et al. (2004).

\section{Pre-treatment}

At first, the OPEFB powder was calculated for its water content. As much as 25 grams the OPEFB powder was soaked in $300 \mathrm{ml}$ of distilled water. It was then heated using a hot plate to boil for 2 hours. After 2 hours, the powder was filtered and the powder was ready to be used for the bleaching process.

\section{Bleaching}

The filtered pre-treatment powder was added with 1000 $\mathrm{ml}$ of distilled water and heated to reach temperature of $80^{\circ} \mathrm{C}$. Afterward, the solution was added to $40 \mathrm{ml}$ of sodium chloride and $2 \mathrm{ml}$ of acetic acid and gently stirred. The addition of sodium chlorite and acetic acid solution was repeated 5 times with the same amount every 1 hour with the mixing total of 5 hours. Subsequently, the solution was filtered using a Blanche cloth and rinsed with distilled water at temperature of $60-70{ }^{\circ} \mathrm{C}$ as much as $300 \mathrm{ml}$ with 4 repetitions. After finished rinsing, the bleaching pulp was ready used for pulp purification process.

\section{Pulp Purification}

The rinsed bleaching pulp was soaked in potassium hydroxide / $\mathrm{KOH}$ solution for 10-15 hours. $\mathrm{KOH}$ solution consisted of 60 grams and $1000 \mathrm{ml}$ of distilled water. The immersion in potassium hydroxide / $\mathrm{KOH}$ solution was repeated for two times. After this process, the solution was heated at temperature of $80{ }^{\circ} \mathrm{C}$ for 2 hours using a water bath. Afterward, the solution was filtered and rinsed using $300 \mathrm{ml}$ of distilled water at a temperature of $60-70{ }^{\circ} \mathrm{C}$ and repeated four times.

Next step, cellulose was bleached one more time with addition of sodium chlorite and acetic acid. Bleching process was the same as the initial process, the differences were the addition of acetic acid and sodium chlorite only once. After the bleaching process was complete, the cellulose was rinsed with $300 \mathrm{ml}$ distilled water at temperature of $60-70{ }^{\circ} \mathrm{C}$ and repeated four times. Then, the cellulose was soaked in distilled water so that the cellulose was not dry.

\section{Solvent Exchanges}

Cellulose pulp produced from purification process was centrifuged to reduce the water content in cellulose. The process of reducing water content using a centrifuge machine was to separate water and cellulose solutions. The centrifuge process was done at $10.000 \mathrm{rpm}$ for 10 minutes at temperature of $20^{\circ} \mathrm{C}$ until the water and cellulose formed sediment. These sediments were collected and water content was calculated.

The amount of PLA and cellulose used in this study was presented in Table 2. Cellulose was added with $300 \mathrm{ml}$ of technical alcohol, which was then stirred using a magnetic stirrer at a speed of $300 \mathrm{rpm}$ for 30 minutes and centrifuged at $10.000 \mathrm{rpm}$ for 10 minutes at temperature of $20^{\circ} \mathrm{C}$ until sediment was formed. This sediment was taken and treatment was repeated three times. After three time repetitions, the solution was replaced with $300 \mathrm{ml}$ of acetone and stirred using a magnetic stirrer with a speed of $700 \mathrm{rpm}$ for 30 minutes. After 30 minutes, centrifuge process continued with a speed of $10.000 \mathrm{rpm}$ for 10 minutes at $20^{\circ} \mathrm{C}$ until sediment was formed. The sediment was separated using acetone solution. Finally, cellulose was soaked in $100 \mathrm{ml}$ of acetone PA.

\section{PLA Composite Manufacturing}

The material composition used for composite manufacturing was presented in Table 2.

The solution used in this process was acetone PA. PLA was dissolved by using $700 \mathrm{ml}$ of acetone PA. PLA was stirred using a magnetic stirrer at a speed of $600 \mathrm{rpm}$. After the PLA was completely dissolved, the cellulose was added gradually into the PLA solution and allowed to stir for 2 hours. After 2 hours, the composite solution was poured on a tray and keep in an acid chamber for 12 hours. After 12 hours, composite sheets were cut into small pieces using scissors measuring approximately of $1 \mathrm{~cm} \mathrm{x} 1 \mathrm{~cm}$. The composites were then dried at the oven with the temperature of $60^{\circ} \mathrm{C}$ for 24 hours. Then the composite was ready used for the next process by mixing it using rheomix rotary mixer at $140^{\circ} \mathrm{C}$ with a $60 \mathrm{rpm}$ rotation for 10 minutes.

\section{Composite test samples preparation}

The composite produced from rheomix process was hot-pressed at $140^{\circ} \mathrm{C}$ through two processes, i.e., melting process for nine minutes (without pressure) and continued with the formation of PLA composite for two minutes at a pressure of 1.5 MPa and cooled for one minute and pressed again for two minutes with a pressure of $1.5 \mathrm{MPa}$. These processes are intended to prevent air bubbles from forming in the sample. The PLA composite was cooled at room temperature for 10 minutes before being removed from the mold. The sample was formed using a dumble shapecutting tool.

Tabel 2. Material composition for composite manufactures

\begin{tabular}{lccc}
\hline $\begin{array}{l}\text { Cellulose } \\
\text { fibre }(\mathbf{g})\end{array}$ & $\begin{array}{c}\text { PLA } \\
(\mathbf{g})\end{array}$ & $\begin{array}{c}\text { Total } \\
\text { material }(\mathbf{g})\end{array}$ & $\begin{array}{c}\text { PHR (Per Hundred } \\
\text { Resin) }\end{array}$ \\
\hline 0 & 60 & 60 & 0 \\
3 & 60 & 63 & 5 \\
6 & 60 & 66 & 10 \\
9 & 60 & 69 & 15 \\
12 & 60 & 72 & 20 \\
\hline
\end{tabular}




\section{Fiber morphology test}

The morphology of bleaching fibres and free hemicelluloses were observed using a microscope with magnification of 100x. The diameter (d) and fiber length (1) were measured for fiber ratio (r) calculation with formula as follows (Sutiya et al. 2012).

$$
\mathrm{r}=1 / \mathrm{d}
$$

The ratio of cellulose fibers was calculated as follows: $\mathrm{r}=1 / \mathrm{d}=5.81 \mu \mathrm{m} / 186.30 \mu \mathrm{m}=0.0311$

\section{Where : \\ r : Ratio of cellulose fibers \\ 1 : Length of cellulose fibers \\ $\mathrm{d}$ : Diameter of cellulose fibers}

\section{PLA composite biodegradation testing}

The method used was a burial method in the soil according to Anita et al. (2013) with modifications. The sample size was $2.5 \mathrm{~cm} \times 1.5 \mathrm{~cm} \times 0.5 \mathrm{~mm}$. The test samples were buried at a depth of $30 \mathrm{~cm}$ in the soil for 6 weeks. Every seven days, the weight of the remaining test sample was measured. Biodegradability testing was done to calculate the weight loss of the test sample. The weight lost test sample was calculated using the formula:

$$
\operatorname{Mt}(\%)=\operatorname{Mo}-\operatorname{Md} / \operatorname{Mox} 100 \%
$$

Where:

Mt : Weight Loss (g)

Mo : Initial weight $(\mathrm{g})$

Md : Weight after testing $(\mathrm{g})$

\section{Data analysis}

Data were statistically analyzed by Variable Analysis in a factorial design, and Tukey Analysis was used for comparison of the mean values (Gaspersz 1994)

\section{RESULTS AND DISCUSSION}

\section{Morphological characteristics of OPEFB cellulose fiber}

The width of the OPEFB fiber before bleaching process and hemicellulose removal was $37.18 \mu \mathrm{m}$. After bleaching process and hemicelluloses removal, the width of cellulose fiber was $5.81 \mu \mathrm{m}$ and cellulose length was $186.30 \mu \mathrm{m}$.

The ratio of OPEFB cellulose fibers after isolated using sodium chlorite solution was 0.0311. Differences of cellulose fiber morphology before and after the isolation process could be seen in Figures 1 and 2.

From Figures 1 and 2, it can be seen that the size of OPEFB fibers after bleaching and hemicelluloses removal has decreased. Before the bleaching and hemicelluloses removal, the width of OPEFB fibers was $37.18 \mu \mathrm{m}$ and after the bleaching and hemicelluloses removal, the width of cellulose fibers was $5.81 \mu \mathrm{m}$.

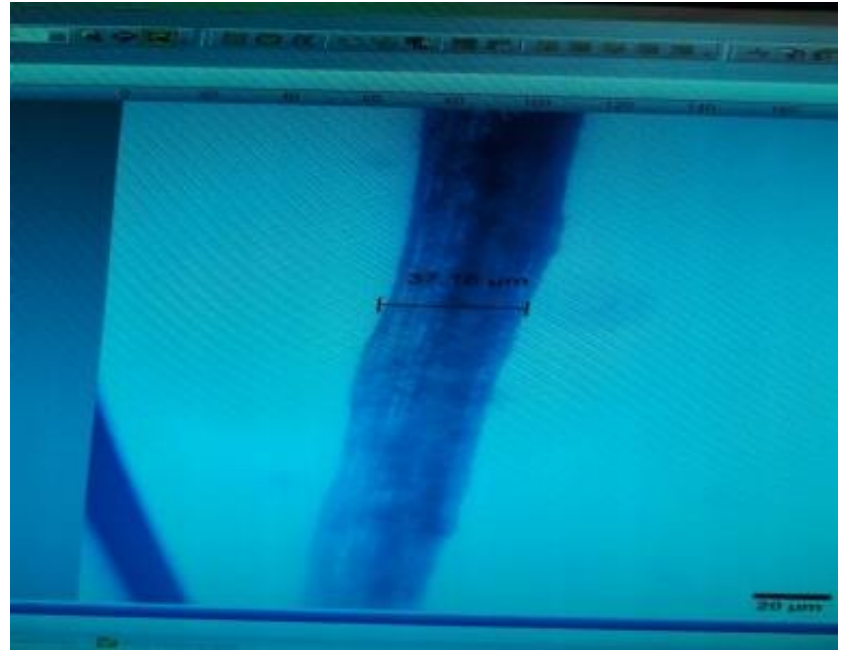

Figure 1. Fiber before isolation process

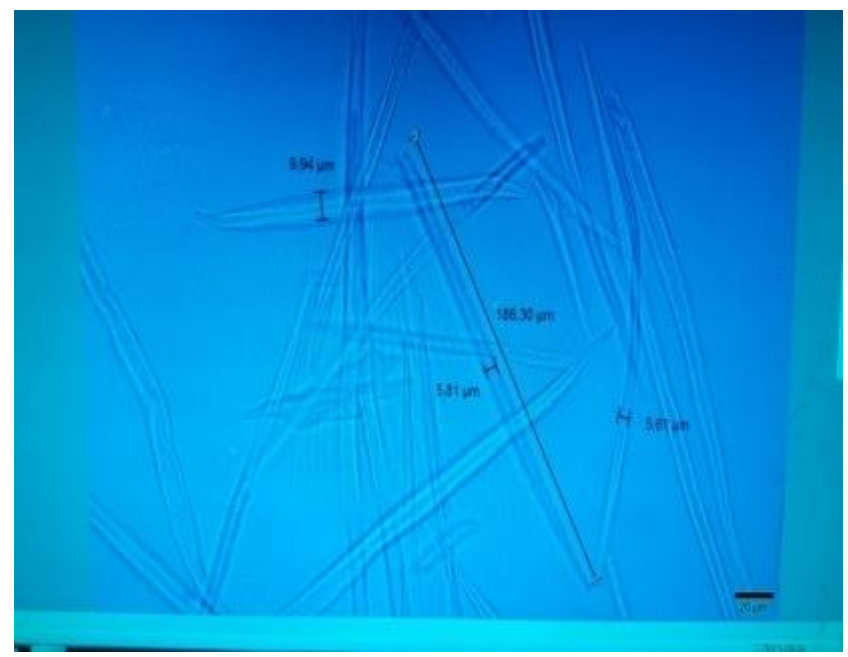

Figure 2. Fiber after isolation process

\section{PLA composite biodegradation testing}

Biodegradation is partially or destruction of all parts of the molecular structure of compounds by physiological reactions catalyzed by microorganisms. One of the methods to determine the biodegradability of material was using soil burial test method.

From the biodegradation testing samples with soil burial test method for 6 weeks, the results showed that the percentage of weight loss was high in the test sample added with 20 PHR cellulose OPEFB, with the weight loss percentage of $0.5539 \%$. The percentage of weight loss of this test sample was higher than the percentage of weight loss in the control test sample $(0.0857 \%)$ (Figure. 3).

The addition of cellulose fiber in the manufactures of bio-plastic causes higher the weight loss of the composites. Weight loss of bio-plastic sample which contains 15 and 20 PHR had significant differences against bio-plastic control as well as bio-plastic which contains 5 and 10 PHR (Tukey`s test $\mathrm{P}<1 \%$ ). 


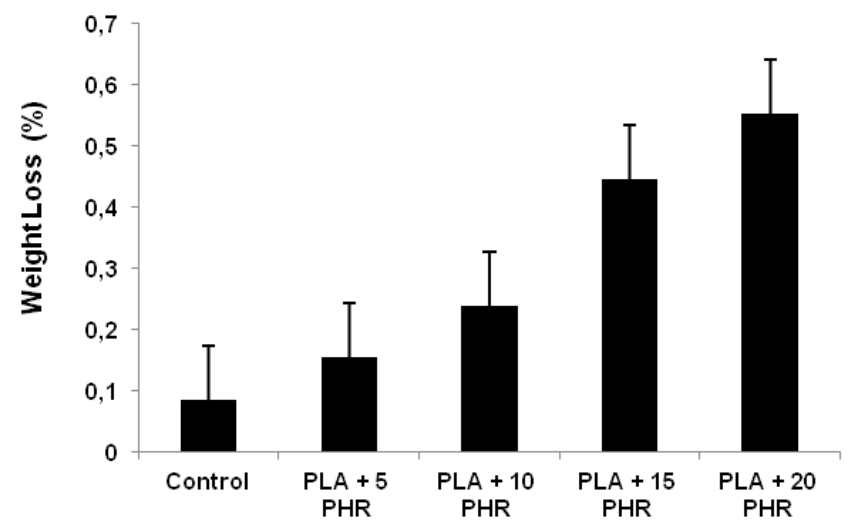

Figure 3. Average percentage of weight loss sample after 6 weeks buried in the soil. Note: Error bars representing standard deviation/SD, showing variation in data; PLA: Polylactic Acid; PHR: Per Hundred Resin.

Nanocellulose particles are a new type of cellulose material which is characterized by an increase in crystallinity, aspect ratio, surface area, and increased dispersion and biodegradability. With this capability, nanocellulose particles can be used as filler polymer reinforcement, additives for biodegradable products, membrane boosters (Ioelovich, 2012). The increase of weight loss of bio-plastics at the addition of 20 PHR cellulose fibers sample was understandable because OPEFB consisted of various chemical compositions including $45.95 \%$ cellulose; $16.49 \%$ hemicelluloses and 22.84\% lignin (Darnoko et al. 2002).

Testing soil burial test on PLA composite samples added with cellulose OPEFB fiber revealed that the highest percentage of weight loss occurred in composite with additional of 20 PHR cellulose OPEFB fiber with the weight loss percentage of $0.5539 \%$. This weight loss is higher than weight loss of control test sample which has the percentage of weight loss of $0.0857 \%$.

The percentage of weight loss of this test sample is lower compared to the previous study conducted by Anuar et al (2012). Their study shows that the addition of 20 PHR of kenaf fiber in PLA composites caused a weight loss of $3.65 \%$ with burial period of 40 days, while the weight loss in control was $0.70 \%$.

The difference in the percentage of weight loss in the test sample was influenced by the ability of cellulose hydrolysis from enzymes and microbes. Cellulose hydrolysis is the process of breaking the chain of cellulose bonds into shorter cellulose and eventually becoming a glucose monomer. However, the process of cellulose hydrolysis is inhibited by chemical structures and the presence of natural bonds of cellulose with hemicelluloses and lignin so that it generally produce low of sugar. Suryanto et al. (2014) stated that the success of cellulose hydrolysis using enzymes and microbes is determined by the degree of crystalline cellulose, cellulose enzyme composition, contact surface area, the ratio between inoculums and substrate and substrate purity.

Furthermore, the ability of plastic degradation is also influenced by various factors, such as soil type, microbial type and humidity (Shakina et al. 2012). Moist soil will provide enough water to support biological activities by soil microbes to penetrate material structures (Wypich, 2003). Plastics having perforated due to microbial activity cause the plastic brittle and easily destroyed. Moreover, additional material such as glycerol also affects speed of plastic degradation due to the ability of glycerol to bond moisture from the air so that the plastic was easily degraded (Khoramnejadian, 2011).

In conclusion, addition of cellulose OPEFB fibers influences on weight loss of bio-plastics. After burial test in the soil for 6 weeks, the higher weight loss of bioplastics was found in PLA with additional cellulose OPEFB fiber was 20 PHR. These results indicate that OPEFB might be potentially useful in the development of bio-based composite in the near future.

\section{ACKNOWLEDGEMENTS}

The authors gratefully acknowledge Directorate General of Higher Education of Indonesia for financial support under "Hibah Kompetensi" program.

\section{REFERENCES}

Anuar H, Zuraida, Ahmad, Fuad F. 2012. Biodegradable PLA-Kenaf fibre biocomposite for cleaner environment. In: Malaysian Science and Technology Congress (MSTC 2010), 9-11 November 2010, Crystal Crown Hotel, Petailing Jaya, Malaysia. [Indonesian]

Anita Z, Akbar F, Harahap H. 2013. Pengaruh penambahan gliserol terhadap sifat mekanik film plastik biodegradasi dari pati kulit singkong. Jurnal Teknik Kimia USU 2(2): 1-5. [Indonesian]

Dewanti DP. 2018. Potensi selulosa dari limbah tandan kososng kelapa sawit untuk bahan baku bioplastik ramah lingkungan. Jurnal Teknologi Lingkungan 19(1): 81-88. [Indonesian]

Darnoko D, Siahaan D, Nuryanto E, Elisabeth J, Erningpraja L, Tobing PL, Naibaho PM, Haryati T. 2002. Teknologi pengolahan kelapa sawit dan produk turunannya. Pusat Penelitian Kelapa Sawit, Medan. [Indonesian]

Gaspersz V. 1994. Experimental design method. Armico, Jakarta.

Herdiyantoro D. 2010. Pengomposan mikrobiologi dan teknologi pengomposan. Laporan Laboratorium Biologi dan Bioteknologi Tanah. Universitas Padjajaran, Jatinangor. [Indonesian]

Ioelovich M. 2012. Optimal condition for isolation of nanocrystalline cellulose particles. J Nanosci Technol 2(2): 9-13.

Khoramnejadian, Shahrzad. 2011. Converting non-biodegradable plastic to biodegradable by using natural polymer to help environment conservation. J Food Agric Environ 9 (2): 477-479.

Mostafa NA, Awatef AF, Hala MA, Aghreed MT. 2018. Production of biodegradable plastic from agricultural wastes. Arabian J Chem 11: 546-553.

Ochi S. 2011. Durability of starch-based biodegradable plastics reinforced with Manila hemp fibers. Materials 4: 457-468.

Sun JX, Sun XF, Zhao H, Sun RC. 2004. Isolation and characterisation of cellulose from sugarcane bagasse. J Polymer Degrad Stab 84: 331339.

Sutiya B, Istikowati WT, Rahmadi A, Sunardi. 2012. Kandungan kimia dan sifat serat alang-alang (Imperata cylindrica) sebagai gambaran bahan baku pulp dan kertas. Jurnal Bioscientiae 9(1): 8-19. . [Indonesian]

Shakina J, Sathiya LK, Allen GRG. 2012. Microbial degradation of synthetic polyesters from renewable resources. Indian J Sci 1 (1): 21-28.

Wypich, George. 2003. Plasticizers use and selection for specific polymers. ChemTec Laboratories, Toronto.

Suryanto H, Eko M, Yudy SI, Rudy S. 2014. Effect of alkali treatment on crystalline structure of cellulose fiber from Mendong (Fimbristylis globulosa) straw. J Key Eng Mater 594: 720-724. 
NUSANTARA BIOSCIENCE

Vol. 10, No. 1, pp. xxxx

ISSN: 2087-3948

February 2018

E-ISSN: 2087-3956

DOI: $10.13057 /$ nusbiosci/n1001xx 